\title{
OWNERSHIP STRUCTURE AND CAPITAL STRUCTURE: EVIDENCE FROM LISTED AGRICULTURAL FIRMS IN NIGERIA
}

\author{
FASUA, Kayode Olushola ${ }^{1}$; ABUBAKAR, Idris Ayokanmi ${ }^{2}$; OJO, Lukman Olatunji ${ }^{3}$ and \\ MFON Umana ${ }^{4}$ \\ ${ }^{1}$ Nigerian College of Accountancy, Kwall, Jos, \\ ${ }^{2}$ Department of Banking and Finance, Nasarawa State University, Keffi, \\ ${ }^{3}$ Department of Accounting, Nasarawa State University, Keffi, \\ ${ }^{4}$ Institute of Governance and Strategic Studies, Nasarawa State University, Keffi
}

DOI: 10.46609/IJSSER.2020.v05i10.022 URL: https://doi.org/10.46609/IJSSER.2020.v05i10.022

\begin{abstract}
This study explores the effect of ownership structure on Nigeria's listed agricultural firms' capital structure over 11 year period from 2009 to 2019. The study adopted ex post facto research design. The population consisted of five agricultural firms listed on the Nigerian Stock Exchange floor. The research used census sampling methods to take the whole population. Primary data from the listed agricultural firms' annual reports were used. The Hausman specification test was conducted to determine the use of random effect or Fixed effect regression, based on the Hausman test results, the study used opted for Random effect regression. The result of the Random Effect Regression showed that managerial ownership and the concentration of ownership have no significant effect on capital structures while institutional ownership has a significant positive influence on capital structure of the listed agricultural firms in Nigeria. The study concludes that ownership structure has a major effect on Nigeria's listed agricultural firms' capital structure. The study recommends that management should allow managers to buy and own shares in their companies. The Securities and Exchange Commission should also strengthen the supervision of major shareholders and diversify the ownership base of listed agricultural companies by reducing the percentage of long-term debt shares held by major shareholders to prevent a few investors from gaining control.
\end{abstract}

Keywords: Capital Structure, Institutional Ownership, Managerial Ownership, Ownership Concentration, Ownership Structure. 


\section{International Journal of Social Science and Economic Research}

ISSN: $2455-8834$

Volume:05, Issue:10 "October 2020"

\section{INTRODUCTION}

The company ownership structure is an important form of corporate governance since different kinds of shareholders can own companies. The relationship between the ownership structure and the capital structure was the most debatable and ongoing topic in corporate finance literature. The effect of the ownership structure on capital structure, especially in the sense of the listed agricultural firms in Nigeria, therefore has to be understood.

The ownership structure is the allocation of equity to votes and properties, but also the recognition of equity owners. These processes are of great importance for corporate governance because they decide on compensation for managers and, thus, economic performance of the organizations they run. As an internal control mechanism, an ownership structure of a corporation may also reduce the range of management opportunism and reduce the corporate debt policy and managerial rewards due to management share ownership (Fama \& Jensen, 1983).

The capital structure discusses how the company's operations are financed by a mix of debt and equity to maximize the value of the company. Essentially, the capital structure can be referred to as the financial system of a company. It is primarily a combination of debt and equity held by a company. It is also used to combine a number of sources of long-term funds and share capital, including reserves and business surpluses (Booth et al., 2001). As a result, the share of debt to equity is a strategic option for corporate managers.

Management shareholders would provide managers with the ability to use the optimal amount of debt. Management shareholders lose wealth if they have less debt than the optimal amount in the corporate capital structure, just as all shareholders (Abor, 2008). Some studies have shown that a significant portion of management shareholdings, such as Ooi (2000) in the United Kingdom, which explores the impact of the debt-equity ratio ownership structure, would have a high debt policy. The outcome has shown that managers with a high percentage of ownership tend to do business that maximizes the resources of shareholders.

Institutional investors also have an important role to play on capital markets and as a result of the privatization policies implemented by developed countries, such as Nigeria, their impact was stressed on corporate governance. Institutional investors have considerable expertise in collecting and analyzing business performance information and can thus reduce agency costs (Chidambaran \& John 2010). While ownership concentration can contribute to reducing the problem of the agency by reducing the degree of managers' opportunism and reducing tension between the two parties (Chen \& Steiner, 2013). Corporate governance and practice in developing countries are still scarce, so Nigeria is still limited to knowledge of the ownership 


\section{International Journal of Social Science and Economic Research}

ISSN: $2455-8834$

Volume:05, Issue:10 "October 2020"

structure and capital structure of agricultural companies in Nigeria. Ownership research focuses primarily on developed economies such as the United States and other European countries.

While a growing literature on ownership structure and capital structure is found, there are a broad range of outcomes based on different theoretical perspectives, methodology collection, variables estimation, and environmental differences. Previous research on the impact of ownership structure on capital markets such as in developed and developing countries was conducted such as the empirical studies of (Salma, 2002; Sarmitha \& Burnnel, 2006; Driffield \& Mohambare, 2007; Caspedes, Gonzales \& Molina, 2008; Hussainy \& Aljifri, 2009; Hassan, 2009; Guo, Ding \& Sun, 2010; Ruan, Tian \& Ma, 2011; LingLing, 2013; Agyei \& Owusu, 2014; Mohamed \& Khairy, 2015; Bulathsin, 2010; However, a few studies have been conducted in Nigeria, looking at the corporate governance and capital structure of Nigeria 's listed oil and gas and food and beverage companies (Hassan, 2010; Samuel, 2015; Hassan, 2015; Usman, 2015). This study deviated from previous studies by looking at the effects of the ownership structure on capital structure of Nigeria's listed agricultural companies, as no previous study looked at Nigeria's listed agricultural companies, covering the period from 2009 to 2019.

The main objective of the study is to examine the impact of the structure of ownership on the capital structure of the agricultural firms listed in Nigeria. The study's other specific objectives are to examine the effect of management ownership, institutional ownership and concentration of ownership on the capital structure of Nigeria's listed agricultural firms. The study covered an eleven (11) year period, from 2009 to 2019. The dependent variable is the structure of capital and the independent factors include managerial ownership, institutional ownership and concentration of ownership.

The remainder of this paper is organized as follows: section 2 reviews the literature and presents the theoretical framework for this study; section 3 discusses the methodology adopted for the study; section 4 presents the study results. Finally, conclusions and recommendations are drowned in section 5 .

\section{LITERATURE REVIEW}

\section{Concept of Ownership Structure}

Bansal (2005) opines that investors and shareholders' committees generally consist of individuals, organizations and organizations with substantial differences in goals, objectives, investment horizons and ability. As general shareholders, they have the right and the power to control the fundamental issues facing the company, including the election of directors, improvements to the company's organic records, acceptance of exceptional transactions, improvements to the company's internal situation and the appointment of auditors. Abel and 


\section{International Journal of Social Science and Economic Research}

ISSN: $2455-8834$

Volume:05, Issue:10 "October 2020"

Okafor (2010) described the ownership structure as the percentage of shares held by managers, institutions, governments, investors outside the country and family investors.

This study measures the composition of ownership with managerial ownership, institutional ownership and concentration of ownership. These ownership structure metrics are explained as follows;

\section{Managerial Ownership}

Managerial ownership is a situation in which the manager owns the business they run, i.e. they act as managers and shareholders of the company. The concepts set out above consider the ownership of shares from the point of view of insiders, which is not different from the shares owned by those responsible for the company. This means that managerial ownership refers to the sum of shares that are held by individuals who handle business affairs while they act as public agent (shareholders) in naira or share units. The opposite result of managers becoming shareholders is that they still have the right to vote and are keen to make the major investment decisions of the business (Krivogorsky, 2006).

Managerial ownership will provide managers with a strong economic incentive to closely track and align ownership and control by meaningful managers through ownership of shares. Management shares are the proportion of shares held by managers of an entity.

\section{Institutional Ownership}

Institutional ownership is the proportion of the stock of a company owned by institutional investors. As a consequence, the institutional ownership of a corporation is one minus a fraction of its share owned by non-institutions, by definition. If we are to determine the preference of institutional investors for a certain category of companies, it should be recognized that the preferences of institutional investors for these companies could be higher than those of individual investors. There are clear fiduciary obligations for institutional investors, such as banks, insurance companies and pension funds.

\section{Ownership Concentration}

Ownership concentration occurs when a controlling block of shares is held by the majority owners, on the basis of which they can influence key strategic decision-making. Ownership focus is an alternate method for solving the agency problem and managing managerial opportunism, in the absence of external corporate governance structures. A high degree of ownership concentration allows efficient oversight and monitoring of managers as an internal method of corporate control (Thomsen \& Pedersen, 2000). 


\section{International Journal of Social Science and Economic Research}

ISSN: $2455-8834$

Volume:05, Issue:10 "October 2020"

In addition, the power they assume to make decisions in the best interest of majority owners on the basis of voting rights pressures managers (Babić \& Nikolić, 2011). In reality, the majority of shareholders are in a position to alleviate agency issues, provided that their large equity stakes provide them with an opportunity to gather information and track executives.

\section{Concept of Capital Structure}

According to Margaritis and Psillaki (2010), capital structure refers to a combination of debt and equity held by a corporation with different sources of funds, in particular long-term capital funds. For them, it is a framework that describes how the company's operations are funded by equity and debt. They argued that it is important to find an optimal capital structure or an optimal combination of debt and equity, as the capital structure maximizes business value. The main goal of the capital structure is therefore to understand the right balance of debt and equity.

In corporate finance, the capital structure can be described as the way a company funds its investments through a combination of hybrid debt securities (Rose, 2007). Creditors 'claims are increased as corporations collect funds by issuing debts, as shareholders' claims are increased by issuing equity securities. The relationship between debt and equity in the capital of a corporation is called the capital structure. According to Abor (2008), the capital structure combines the debt with the equity used by the company to fund its activities. In line with this, the use of fixed-fee sources of funds is known as financial leverage, along with equity in the capital structure.

\section{Empirical Review}

\section{Managerial Ownership and Capital Structure}

Ruan et al., (2011) studied the impact of management ownership on the options for corporate capital structure, using a sample of Chinese civil-owned companies listed on the Chinese stock exchange from 2002 to 2007. Empirical results revealed a non-linear relationship between management ownership and company valuation. By way of management ownership, but in the opposite direction, the capital structure is pushed into nonlinear form to control management ownership on corporate valuations. The effects of concurrent regressions show that managerial ownership has significant effect on capital structure.

LingLing (2013) analyzed the effect of the ownership structure on capital structure of nonfinancial Chinese firms between 2007 and 2012. Pooled OLS regression is used to analyze the effect of ownership variables on the company's capital structure decision. The study found no proof that management ownership influences the capital structure of the company. The effect of corporate governance on the Ghanaian capital structure was assessed by the empirical work of Agyei and Owusu (2014). The study covered the period 2007-2011 and data from eight 


\section{International Journal of Social Science and Economic Research}

ISSN: $2455-8834$

Volume:05, Issue:10 "October 2020"

randomly selected manufacturing companies listed on the Ghana Stock Exchange were collected at firm level. In the study, a multivariate regression analysis was used. The study shows a clear correlation between the leverage ratio and management and institutional ownership.

Hassan (2015) analyzed the impact of the ownership arrangement on the capital structure of Nigeria's listed oil and gas firms. The analysis proxied the structure of ownership with management stakes, institutional shareholdings, block holdings and international ownership, while the structure of capital was proxy with leverage. The study used 42 paneled observations for firms-year, panel regression was used. The study used criteria to arrive at a sample size consisting of 6 Nigerian oil and gas companies out of 8 oil and gas companies listed. From the audited annual reports of the sampled companies from 2007 to 2013, secondary data sources were collected. The findings showed that management shareholding and leverage have a negative and substantial relationship.

From 2003 to 2012, Samuel (2015) analyzed the effects of corporate governance features on the capital structure of listed companies in the Nigerian food and beverage industry. After giving all companies equal opportunity to be selected by random sampling techniques, the sample size of six out of nine companies emerged as sample size. Using the Pearson correlation coefficient and multivariate regression analysis, data from sample companies ' annual reports are analyzed. Findings showed management ownership has a negative leverage relationship.

Mohamed and Khairy (2015) discussed Egypt's relationship between ownership and corporate financial leverage. The study used a sample of 36 non-financial firms from the 50 most active Egyptian firms listed for 2007-2011. Multiple Least Square was used for data processing. Results showed that organizational leverage is insignificantly connected to management ownership.

Bulathsinhalage and Pathirawasam (2017) empirically studied the effect of corporate governance on the capital structure of the listed companies in Sri Lanka. The study sample consisted of 138 listed non-financial firms for the five-year period 2009-2013. Managerial ownership was used as part of the variables of corporate governance, while the debt ratio was used as a metric capital structure and ROA and scale as control variables. Multiple regression analysis of was used to empirically evaluated the variables. Results have shown that management ownership has no major impact on the structure of capital.

\section{Institutional Ownership and Capital Structure}

Hussainy and AlJifri (2009) looked at the relationship between corporate governance and corporate capital structures. These mechanisms have been classified into two groups of 26 internal and external mechanisms. The study involved 71 organizations using multiple 


\section{International Journal of Social Science and Economic Research}

ISSN: $2455-8834$

Volume:05, Issue:10 "October 2020"

regressions. The research results showed that institutional investors adversely impacted the debtto - equity ratio.

The Usman (2015) research examined the effect of corporate governance systems on Nigeria's listed food and beverage capital structure over 10 years, from 2004 to 2013. During the research era, secondary data from annual reports and NSE fact books were used. The generalized Least Square Regression Technique was used to investigate the relationship between the capital structure and various independent variables in the model. Research showed that institutional control of explanatory variables does not significantly affect resource structure.

\section{Ownership concentration and Capital Structure}

Salma (2002) assessed the effects of the concentration of ownership and the transition to capital structure. Study uses a multi-panel regression approach to analyze the complex capital structure of a panel of 766 Western European firms. The study results have shown that the transaction costs and the agency costs inherent in the concentration of ownership are main determinants of the dynamics of capital structure. Similarly, Driffield and Mohambare (2007) conducted a report on the relationship between the concentration of ownership and the capital structure in Indonesia , Malaysia and Thailand. The result of the study suggested a significant positive relationship between leverage and the concentration of ownership.

Caspedes et al . ( 2008) analyzed the relationship between concentration of ownership and variable capital structure in seven Latin American countries from 1996 to 2005 using a multiregression method. The findings showed a positive relationship between concentration of ownership and leverage. Hassan (2009) studied the impact of the concentration of ownership on the capital structure and the valuation of the company. The research used non-financial data on the Australian Stock Exchange from 1993 to 2008. The results showed a significant relationship between the concentration of firm value ownership, the concentration of leverage and firm value leverage.

Guo et al. (2010) examined the impact of the ownership system on the degree of leverage. The research used 365 companies from 1997 to 2009. Multiple regression panel was used for data analysis. The study suggested that ownership adversely affects leverage. Further research has also shown that the change in market leverage is positively related to ownership concentration.

\section{Theoretical Framework}

Stewardship Theory 
International Journal of Social Science and Economic Research

ISSN: $2455-8834$

Volume:05, Issue:10 "October 2020"

Donaldson and Davis (1991) introduced stewardship. It is a theory that has been attributed to organizational behavior researchers for the past 20-25 years, but it has been developed and applied in a number of ways for far longer than that. Essentially, stewardship holds that directors act as stewards and are not concerned with promoting their own economic interests (Sundaramuthy \& Lewis, 2003). Directors serving as stewards are also thinking about serving honorably and doing the right thing.

Stewardship philosophy is characterized as service to others, not self-interest. The theory of stewardship suggests that people, including managers, can also be guided by considerations of fairness, justice and concern for the interests of others, and managers also see themselves as business managers who can be trusted to do successful, competent work and who are so closely linked to the goals of the organization that they take precedence.

\section{Agency Theory}

As companies make financial decisions, Jensen and Meckling (1976) proposed agency theory sees potential conflicts of interest between related parties. The Agency's theory postulates that ownership and management separation are the result of agency costs resulting from a conflict of interest between corporate managers and shareholders. Conflict is going to decide on the financial structure.

To overcome this problem, companies should change the capital structure. Debt contribution continues to limit free cash flow overinvestment if company anticipates potential growth opportunities. Debt may also be used to demonstrate management's willingness to pay cash flows.

\section{METHODOLOGY}

This study adopts ex post facto research design. As of 31 December 2019, the population of this study consists of five (5) agricultural companies listed on the floor of the Nigerian stock exchange market. The research spans an eleven-year period that is between 2009 and 2019. The research used secondary data derived from the annual reports and accounts of the NSE-listed agricultural firms sampled. Multiple panel regression techniques is used for data analysis.

Multiple panel regression equation is econometrically expressed as follows:

$\mathrm{CS}_{\mathrm{it}}=\beta_{\mathrm{o}}+\beta_{1} \mathrm{MO}_{\mathrm{it}}+\beta_{2} \mathrm{IO}_{\mathrm{it}}+\beta_{3} \mathrm{OC}_{\mathrm{it}}+\beta_{4} \mathrm{FS}_{\mathrm{it}}+\varepsilon_{\mathrm{it}}$

Where;

$\mathrm{CS}=$ Capital Structure

MO = Managerial Ownership 
International Journal of Social Science and Economic Research

ISSN: 2455-8834

Volume:05, Issue:10 "October 2020"

$\begin{array}{lll}\mathrm{IO}= & \text { Institutional Ownership } \\ \mathrm{OC}= & \text { Ownership Concentration } \\ \mathrm{FS} & = & \text { Firm Size (Control Variable) } \\ \beta_{\mathrm{o}}= & \text { Intercept or regression constant } \\ \beta_{\mathrm{it}}= & \text { Coefficients to be estimated for firm í in period } \mathrm{t} \\ \beta_{1}-\beta_{4}= & \text { Regression Coefficients } \\ \varepsilon & = & \text { Error Term }\end{array}$

Table 1: Variable Measurement

\begin{tabular}{|l|l|}
\hline Variables & Measurement \\
\hline Capital Structure & $\begin{array}{l}\text { Debt/Total Assets (Agyei \& Owusu, 2014; Samuel, } \\
\text { 2015; Usman, 2015) }\end{array}$ \\
\hline Managerial Ownership & $\begin{array}{l}\text { Percentage of shares held by top managers (Agyei } \\
\text { \& Owusu, 2014; Mohamed \& Khairy, 2015; } \\
\text { Samuel, 2015) }\end{array}$ \\
\hline Institutional Ownership & $\begin{array}{l}\text { Percentage of shares held by institutions (Agyei \& } \\
\text { Owusu, 2014; Mohamed \& Khairy, 2015; Usman, } \\
\text { 2015) }\end{array}$ \\
\hline Ownership Concentration & $\begin{array}{l}\text { Percentage of shares held by block shareholders } \\
\text { with equity ownership at least 5per cent (Mohamed } \\
\text { \& Khairy, 2015; Usman, 2015) }\end{array}$ \\
\hline Firm Size & $\begin{array}{l}\text { Log of Total Asset (Control Variable) (LinLing, } \\
\text { 2013; Agyei \& Owusu, 2014; Mohamed \& Khairy, } \\
\text { 2015; Usman, 2015) }\end{array}$ \\
\hline
\end{tabular}

Source: Researcher Computation, 2020.

RESULTS AND DISCUSSIONS

Descriptive Statistics

Table 2: Summary of Descriptive Statistics

\begin{tabular}{lccccc}
\hline STATISTICS & CS & MO & IO & OC & FS \\
\hline Mean & 0.452182 & 0.356436 & 0.493927 & 0.608564 & 5.357926 \\
Maximum & 0.890000 & 0.773000 & 0.752000 & 0.782000 & 8.290870 \\
Minimum & 0.110000 & 0.012000 & 0.123000 & 0.434000 & 3.012980 \\
Std. Dev. & 0.201013 & 0.176915 & 0.127079 & 0.099775 & 1.378931 \\
Skewness & 0.120149 & 0.381748 & -0.601514 & 0.007115 & 0.345654 \\
Kurtosis & 2.350072 & 2.508948 & 3.113450 & 2.784688 & 2.370695 \\
Jarque-Bera & 1.100341 & 1.888468 & 3.346175 & 3.385218 & 2.002757 \\
Probability & 0.576851 & 0.388977 & 0.187667 & 0.184039 & 0.367373
\end{tabular}


International Journal of Social Science and Economic Research

ISSN: 2455-8834

Volume:05, Issue:10 "October 2020"

\begin{tabular}{llllll}
\hline Observations & 55 & 55 & 55 & 55 & 55 \\
\hline
\end{tabular}

\section{Source: Eview 10 Output, 2020.}

The table above shows that $0.452182,0.356436,0.493927,0.608564$, and 5.357926 are respectively the mean of capital structure, managerial ownership, institutional ownership, ownership concentration, and geometric mean of firm scale. It shows the average number of listed agricultural firms in Nigeria in terms of capital structure, managerial ownership, institutional ownership, concentration of ownership, and business size. The standard deviation of all variables is less than the mean numbers, which shows that the mean is not widely scattered from the results. The skewness value is similar to zero for all variables, meaning that the variables' distribution is symmetrical in nature. For both variables, the kurtosis values are also closer to 3 , suggesting that the form is a natural distribution.

This research uses the Jarque-Bera test analysis for the normality test. Since their P-values are more than 0.05 , all variables are typically distributed, whereas capital structure, institutional ownership, ownership concentration and business size are usually distributed since their P-value is more than 0.05 .

\section{Correlation Coefficient Matrix}

Table 3: Correlation Analysis

\begin{tabular}{cccccc}
\hline VARIABLES & CS & MO & IO & OC & FS \\
\hline CS & 1 & & & & \\
MO & 0.018813860 & 1 & & & \\
IO & 0.127945093 & 0.088298132 & 1 & & \\
OC & -0.0409386 & -0.14660300 & 0.051237139 & 1 & \\
FS & -0.10591662 & -0.20177395 & -0.23450111 & -0.03701416 & 1 \\
\hline
\end{tabular}

\section{Source: Eview 10 Output, 2020.}

The correlation result indicates that Managerial Ownership, Institutional Ownership and Ownership Concentration are found to be negatively related to Capital Structure of listed agricultural firm in Nigeria. However, Firm Size and Capital Structure are found to be positively related. It is also indicated in the results that the explanatory variables are not highly correlated as none of the independent variables has correlation above 0.80 . 
International Journal of Social Science and Economic Research

ISSN: 2455-8834

Volume:05, Issue:10 "October 2020"

Variance Inflation Factor

Table 4: Variance Inflation Factor

\begin{tabular}{lll}
\hline Variable & VIF & 1/VIF \\
\hline MO & 1.071674 & $5.61 \mathrm{E}-07$ \\
IO & 1.062949 & 0.051853 \\
OC & 1.029522 & 0.081471 \\
FS & 1.099954 & 0.000427 \\
C & & 0.060122 \\
\hline
\end{tabular}

Source: Eview 10 Output, 2020.

The VIF for MO, IO, OC and FS are 1.07, 1.06, 1.02, 1.12 and 1.09 respectively. This indicates that, the VIF values are less than 10. Thus, the study concludes that there is no problem of multicollinearity. Also, that multi-collinearity exists only when the VIF is greater than 10 (Neter, Wasserman \& Kutner, 1990).

Random Effect Model Regression Results

Table 5: Random Effect Model Regression Results

\begin{tabular}{lllll}
\hline Variable & Coefficient & Standard Error & t-statistics & Prob \\
\hline C & 0.723714 & 0.4284598 & 1.69 & 0.091 \\
MO & 0.005019 & 0.0273498 & 0.18 & 0.854 \\
IO & -0.37226 & 0.6618065 & -6.02 & 0.000 \\
OC & 0.014772 & 0.0368869 & 0.40 & 0.688 \\
FS & 0.716176 & 0.0958215 & 7.47 & 0.000 \\
R $^{2}$ & 0.38 & & & \\
Adj. R & & & & \\
F-Statistics & 0.31 & & & \\
Prob (F-Statistics) & 8.22 & & & \\
Hausman Prob>Chi2 & 0.0084 & & & \\
Heteroskedasticity Sig & 0.6556 & & & \\
Breusch-Godfrey $\quad$ Ob. & 0.80 & & & \\
\hline
\end{tabular}


International Journal of Social Science and Economic Research

ISSN: 2455-8834

Volume:05, Issue:10 "October 2020"

$\mathrm{R}$

\section{Source: Eview 10 Output, 2020.}

\section{Dependent variable: Capital Structure (CS)}

The regression line $\mathrm{CS}=0.724+0.005 \mathrm{MO}-0.372 \mathrm{IO}+0.015 \mathrm{OC}+0.716 \mathrm{FS}$ reveals that capital structure increases by 0.005 units per unit increase in management ownership, decreases by 0.372 units per unit increase in institutional ownership, increases by 0.015 units per unit increase in ownership concentration, and increases by 0.71 units per unit increase in firm size.

The significant value or P-value of institutional ownership and firm size is 0.000 and 0.000 respectively, this significant value or P-value is less than the t-value of 0.05 , suggesting that institutional ownership has positive effects on the capital structure of listed Nigerian agricultural firms. The $8.22 \mathrm{~F}$-Statistics and its corresponding $0.0084 \mathrm{P}$-value suggest the model is fit. The Coefficient of Determination $\left(\mathrm{R}^{2}\right)$ of 0.38 shows that approximately $38 \%$ of the difference in capital structure can be explained by managerial ownership, institutional ownership, ownership concentration and firm scale. The remaining $62 \%$ was due to other independent variables not captured in regression. The study therefore rejects Null Hypothesis, which argues that the ownership structure does not have a significant effect on the capital structure of the listed agricultural firms in Nigeria.

The Breusch Pegan-Godfrey Heteroskedasticity Test shows 0.66 observed R squared, indicating that the results are homogeneous. Thus, the p-value of 0.66 , which is greater than 0.05 , is based on the null hypothesis that the residuals are not heteroskeasticity but homokesdasticity and are desirable. The Hausman Specification Test shows that the Random Effect Model is best suited to the Fixed Effect Model with a P-value of 0.6556, which is less than the critical 0.5. The Breush - Godfrey serial correlation LM test for serial correlation, as shown in the table above, was performed on the residuals and the results showed an R-square observed of 0.80 , which is greater than 0.05 , leading us to refute the existence of serial correlation in the residual.

The regression line $\mathrm{CS}=0.724+0.005 \mathrm{MO}-0.372 \mathrm{IO}+0.015 \mathrm{OC}+0.716 \mathrm{FS}$ indicates that the capital structure increases by 0.005 units per unit increase in ownership. The significant value or $\mathrm{P}$-value of 0.854 exceeds the $\mathrm{t}$-value of 0.05 , indicating that management ownership has no significant effect on the capital structure of the listed Nigerian agricultural firms. The regression line indicates that the capital structure reduces institutional ownership by 0.375 units per unit. The significant value or P-value of 0.000 is less than the t-value of 0.05 , indicating that the alternative inference is that institutional ownership has significant negative effects on the capital structure of the listed Nigerian agricultural firms. Finally, the regression line indicates that the capital structure reduces the concentration of ownership of each unit by 0.014 units. The 


\section{International Journal of Social Science and Economic Research}

ISSN: $2455-8834$

Volume:05, Issue:10 "October 2020"

significant value or P-value of 0.688 is greater than the t-value of 0.05 , indicating that the null assumption is that the concentration of ownership does not have a significant effect on the capital structure of the listed Nigerian agricultural firms.

\section{Discussion of Findings}

As a result of the regression, management ownership has no major influence on the composition of resources. This means that the capital structure remains the same, regardless of the degree of managerial ownership. The finding is in tandem with the results of LingLing (2013); Bulathsinhalage and Pathirawasam (2017) in previous works. Also, the analysis of Ruan, Tian and Ma (2011); Agyei and Owusu (2014); Hassan (2015); Samuel (2015) is contrary to the observation.

A important positive impact was found in the case of institutional ownership and capital structure. This means that when there is a rise in institutional ownership, the capital structure rises. In previous research, such as Agyei and Owusu (2014); Mohamed and Khairy (2015), this finding is consistent with the results. The result is also contrary to the research of Usman (2015) by Hussainy and AlJifri (2009). Based on the outcome of the regression, ownership concentration has no major impact on the structure of resources. The results of previous studies such as Salma (2002); Driffield and Mohambare (2007); Caspedes et al., (2008); Hassan (2009); LingLing (2013); Mohamed and Khairy (2015); Hassan (2015); Usman (2015) are contrary to this finding.

\section{CONCLUSIONS AND RECOMMENDATIONS}

Managerial ownership does not affect the composition of wealth. This shows that by selecting various levels of debt, the alignment of managerial interest with other shareholders by equity ownership influences the funding structure of the company. But this result is not statistically important and the potential reason could be that the base of management ownership is not large enough to mount pressure on mangers or threaten to leave when managers expect the construction of the empire or because of operational efficiencies. This means that the capital structure remains the same, regardless of the degree of managerial ownership. The study also shows that a good relationship with a firm debt ratio is demonstrated by the proportion of managerial ownership. One potential reason for this condition may be that as businesses have more management ownership, they increase insurance against risks and this increases the capacity of the company to collect external debt.

In the same way, institutional ownership prefers debt-to-debt equity in Nigeria 's listed agricultural companies. That means a negative impact on the leverage position is indicated by the number of institutional shareholders. The negative relationship between institutional ownership 


\section{International Journal of Social Science and Economic Research}

ISSN: $2455-8834$

Volume:05, Issue:10 "October 2020"

and the structure of capital indicates that, because of the tight monitoring already placed in place by institutional owners, institutional owners avoid accepting significant quantities of debt. This study concludes that agricultural firms with a strong presence in institutions appear to have low leverage, and agricultural firms with a stronger presence in institutions are correlated with lower leverage.

Again, the concentration of ownership does not impact the capital structure of Nigeria's listed agricultural firms. Ownership concentration is positively linked to the leverage ratio, which suggests that ownership concentration causes managers to raise the degree of gearing, but this effect is statistically negligible. However, this result is not a statistically relevant potential reason that the base of ownership concentration is not large enough to mount pressure on mangers or threaten to leave when managers assume empire creation or because of operational efficiencies.

The study offers the following recommendations based on the findings of the study:

i. $\quad$ Management should encourage managers to buy and own shares in their companies. This will enable them to judiciously utilize debt capital in such projects that will improve the performance of the business. Excess cash flow will not be used to finance unprofitable projects because if that is done and they find it difficult to service the obligations of debt holders, they can be replaced by some other people.

ii. The Securities and Exchange Commission should enhance the supervision of major shareholders and diversify the ownership structure of listed Agricultural firms by reducing the percentage of long-term debt' shares that major shareholders' held in order to avoid concentration of power to determine the capital structure of the Agricultural firms.

iii. Institutional investor with substantial ownership may also induce more debt into the agricultural firms in order to keep its management from making value-endangering decisions as for instance empire building.

\section{References}

Abel, E. E., \& Okafor, F. O. (2010). Local corporate ownership and capital structure decisions in Nigeria: A developing country perspective. Corporate Governance, 10(3), 249-260.

Abor, J. (2008). Corporate governance and financing decisions of Ghanaian listed firms, corporate governance. International Journal of Business in Society, 7(1), 83-92.

Agyei, A., \& Owusu, A. R. (2014). The effect of ownership structure and corporate governance on capital structure of Ghanaian listed manufacturing companies. International Journal of Academic Research in Accounting, Finance and Management sciences, 4(1), 109-118. 


\section{International Journal of Social Science and Economic Research}

ISSN: $2455-8834$

Volume:05, Issue:10 "October 2020"

Babić, V., \& Nikolić, J. (2016). Key factors of corporate governance model development in transition economies. Ekonomske Teme, 4, pp.747-761.

Bansal, C.L. (2005). Corporate governance: Law practice and procedures with case studies. New Delhi: Taxmann Allied Service (P) Ltd.

Booth, L., Aivazian, V., Dermirguc-kunt, A., \& Maksimovic, V. (2001). Capital structures in developing countries. The Journal of Finance, 4(1), 87 -130.

Bulathsinhalage, S., \& Pathirawasam, C. (2017). The effect of corporate governance on firms' capital structure of listed companies in Sri Lanka. Journal of Competitiveness, 9(2).

Cespedes, J., Gonzales, M., \& Molina, C. (2008). Ownership concentration and the determinants of capital structure in Latin America. Journal of Business Research, 63(3), 248-254.

Chen, C., \& Steiner, T., (2013). Managerial ownership and agency conflicts: A nonlinerar simultaneous equation analysis of managerial ownership, risk taking, debt policy and dividend policy. Financial Review, 34, 119-136.

Chidambaran, N. K., \& John, K. (2010). Managerial horizon, voluntary disclosure and firm risk. Available at http://www.bnet.fordham.edu/chidambaran/G_Horizon.pdf, accessed on $13 / 08 / 2014$.

Donaldson, L., \& Davis, J. H. (1991). Stewardship theory or agency theory: CEO governance and shareholder returns. Australian Journal of Management, 16, 49-64.

Driffield, N.L., \& Mahambare, V. (2006). How does ownership structure affect capital structure and firm performance? Recent evidence from East Asia. ESRC workshop on 'Corporate Governance, Corporate Restructuring and Corporate Finance in Transition Economies' held in London in September 2005.

Fama, E., \& Jensen, M. (1983). Separation of ownership and control. Journal of Law and Economics, 26(2), 301-325.

Guo, J., Ding, L., \& Sun, J. (2010). Company ownership and capital structure.

Hassan, H. (2009). The relationship between corporate governance monitoring mechanism, capital structure and firm value. Accounting review, 10.

Hassan, I. (2015). Ownership structure and capital structure of listed oil and gas companies in Nigeria. Journal of management research and development, 4(1). 


\section{International Journal of Social Science and Economic Research}

ISSN: 2455-8834

Volume:05, Issue:10 "October 2020"

Hassan, S.U. (2010). Determinants of capital structure in the Nigerian listed insurance firms. International Conference on Management (Icm 2011) Proceeding.

Hussainy, K., \& Aljifri, K. (2009). Corporate governance mechanisms and capital structure in UAE. The Journal of Finance, 35(5), 1223-34.

Jensen, M.C., \& Meckling, W.H. (1976). Theory of the firm: Managerial behaviour, agency costs and capital structures. Journal of Financial Economics, 3, 305-360.

Krivogorsky, V. (2006). Ownership, board structure, and performance in continental Europe. The International Journal of Accounting, 41, 176-197.

LingLing, Z. (2013). The impact of ownership structure on capital structure: Evidence from listed firms in China. Master Thesis submitted to School of Management and Governance Financial Management. University of Twente.

Margaritis, D., \& Psillaki, M. (2010). Capital structure, equity ownership and firm performance. Journal of Banking and Finance, 34(3), 621-632.

Mohamed, G.A., \& Khairy, E. (2015). The effect of board characteristics and ownership structure on the corporate financial leverage. Accounting and Finance Research, 5(1); 114.

Neter, J., Wasserman, W., \& Kutner, M. H. (1990). Applied linear regression models. (3 ${ }^{\text {rd }}$ ed.). USA: IRWIN Book Team.

Ooi, J. T. L. (2000). Managerial opportunism, and the capital structure decisions of property companies. Journal of Property Investment and Finance, 18(3), 316-31.

Rose, S.A. (2007). The determination of financial structure: The incentive signaling approach. Bell Journal of Economics, pp. 23-40.

Ruan, W., Tian, G., \& Ma, S. (2011). Managerial ownership, capital structure and firm value: Evidence from China's civilian-run firms. Australasian Accounting Business and Finance, 5(3), 73-92.

Salma, B. (2002). Corporate governance impact on bank performance: Evidence from Europe. Corporate Ownership \& Control, 13(4). Pp 16091-16103.

Samuel, A.A. (2015). Corporate governance attributes and capital structure of listed firms in the Nigerian food and beverages industry. International Journal of Public Administration and Management Research, 3(1). 
International Journal of Social Science and Economic Research

ISSN: 2455-8834

Volume:05, Issue:10 "October 2020"

Schillemans, T., \& Basuioc, M. (2015). Predicting public sector accountability: From Agency drift to forum drift. Journal of Public Administration Research and Theory, 25, 191.

Sundaramuthy, C., \& Lewis, M., (2003). Control and collaboration: Paradoxes of governance. Academy of Management Review, 28, 397.

Thomsen, S., \& Pedersen, T. (2000). Ownership structure and economic performance in the Largest European Companies. Strategic Management Journal, 21(6), 689-705.

Usman, D.A. (2015). Corporate governance mechanisms and capital structure of listed foods and beverages firms in Nigeria. A Dissertation Submitted to the School of Postgraduate Studies, Ahmadu Bello University, Zaria, in Partial Fulfillment of the requirements for the Award of Masters of Science (M. Sc) Degree in Accounting and Finance. Department of Accounting Faculty of Administration Ahmadu Bello University, Zaria. 